\title{
Practical utility of customer relationship management practices - a discriminant function analysis
}

\author{
S. Sharmila ${ }^{1}$, N. Jamunarani ${ }^{2}$ \\ ${ }^{1}$ Research Scholoar, Dept. of Commerce, Annamalai University, Anamalainagar, Tamil Nadu, ${ }^{2}$ Assistant Professor, Dept. of \\ Commerce, Government Arts College for Women, Pudukkottai, Tamil Nadu, India \\ *Corresponding Author: \\ Email: sharmilaknc09@gmail.com
}

\begin{abstract}
In the present day, organizations face with numerous challenges such as increased uncertainty, cutthroat competition, financial crises, technological advancement, labour turnover, etc. The banking sector is highly complex and competitive with little stability due to the entry of national and international financial institutions in the emerging economies. The outstanding customer relationship management in the new generation private banks can improve their ability to lure affluent prospects, elevate the banks' profitability, lower operation costs, and create greater customer loyalty. At this juncture, the present study is undertaken to study how the managers differ from staff of the banks in terms of their level of acceptance towards practical utility of customer relationship management practices of the new generation private banks in Puducherry. For collecting primary data from the customers, multi-stage sampling technique was adopted. The primary data were collected from 66 employees with the help of schedule. The secondary data were collected from journals, magazines, government reports, books and unpublished dissertations. The results showed that 'attracts new customer' is the maximum discriminating variable $\left(\mathrm{R}^{2} \%=24.11 \%\right)$ between managers and staff, followed by 'creates friendly environment' (12.53\%), 'growth in banking service' (9.36\%) and 'boosts customer confidence' $(6.20 \%)$. The contribution of all other items discriminating between managers and staff are less than $5 \%$.
\end{abstract}

Keywords: Customer relationship management, Relationship marketing, Service performance, Service quality in banks, etc.

\section{Introduction}

In the present day, organizations face with numerous challenges such as increased uncertainty, cutthroat competition, financial crises, technological advancement, labour turnover, etc. The competitive nature of business environment saddled management of various organizations with the responsibility of treating customer as king. At present banks, insurance companies, and other service providers recognize the importance of customer relationship management and its role to acquire new customers, retaining existing customers and maximizing their lifetime value. The banking sector is highly complex and competitive with little stability due to the entry of national and international financial institutions in the emerging economies. To understand the credit worthiness of a customer, bank has to develop a close relationship with customers. Thus, in this era of increased competition, it will be imperative for the banks to develop long-term relationships with customers by offering quality services. Customer relationship management creates a customer oriented organization that maximizes customer value and long-term organizational profitability through realization of mutual beneficial, durable relationships with customers. Therefore, it is necessary to bring dynamic changes in banks with the objective of business growth with effectively managing customers as assets, systematically collecting, analyzing and disseminating customer information and use of customer information for acquiring, retaining and better servicing customers.

\section{Statement of the Problem}

In this era of increased competition, so as to improve standards it will be benefitable for the banks to develop long-term relationship with the customers. Increasing competition from both inside and outside the industry is leading to compression of profits and forcing banks to serve efficiently only with the available resources to satisfy customers. There exists a strong need for maintaining customer relationship management in the banks. In today's era of liberalization and globalization, every industry faces increasing competition. Banking industry is no exception. With the extreme competition among the banks and broad use of technology for service innovation and delivery, banks are attempting to satisfy and retain the customers. It is apparent that now there are progressively marketing oriented banks, using information technology systems that are focused on individual customers. However, the core issues faced by banks today are on the fronts of customer's service expectations, customer relations, cutting operational costs, eliminating inflexibility to change, technological advancements and managing competition. Historically, banking sector operated in a relatively stable environment and for long, Indian banks had presumed that their operations are customer focused, simply because they had customers. Today this sector is facing a forceful competition and many banks have lost a substantial share of their decade old customers to comparatively newly entered private banks and foreign banks. Thus, customer relationship management is an effective tool for the bankers to acquire new customers 
and to retain the existing ones. The outstanding customer relationship management in the new generation private banks can improve their ability to lure affluent prospects, elevate the banks' profitability, lower operation costs, and create greater customer loyalty. At this juncture, the present study is undertaken to study how the managers differ from staff of the banks in terms of their level of acceptance towards practical utility of customer relationship management practices of the new generation private banks in Puducherry.

\section{Objectives of the Study}

The main aim of the study is how do the managers of new generation private banks differ from staff in terms of their acceptance on practical utility of CRM practices? Do the opinions on the items like, increases customer base, retention of existing customers or increases bank image differ between mangers and staff? In general, what are all the variables which discriminate the employees from staff?

\section{Research Design}

The present study is empirical in character based on survey method, and is an endeavour for discovering unrevealed truths in the practical utility of customer relationship management practices of new generation private banks in Puducherry. The study is confined to savings bank and current account holders. Further, the study is confined to 6 new generation private banks namely HDFC Bank, ICICI Bank, Axis Bank, Yes Bank, Kotak Mahindra Bank and IndusInd Bank. The area of the study is Puducherry Union Territory. Puducherry Union Territory constitutes four regions: Puducherry, Karaikal, Mahe and Yanam divided into 15 communes. For collecting primary data from the customers, multi-stage sampling technique was adopted. At the first stage, 2 regions namely Puducherry and Karaikal were selected out of 4 regions. In the second stage, 60 per cent of the branches i.e. 11 branches were selected out of 18 branches of 6 new generation private banks in the Puducherry and Karaikal regions. In the final stage, from each of the branches 6 employees i.e. 2 managers and 4 staff were selected. The following table shows the sampling distribution of the present study.

Table 1: Sampling distribution

\begin{tabular}{|l|c|c|c|c|}
\hline \multirow{2}{*}{ Bank } & \multirow{2}{*}{ No. of Branches } & \multicolumn{3}{c|}{ Sample } \\
\cline { 3 - 5 } & & \multirow{2}{*}{ Branches } & \multicolumn{2}{|c|}{ Employees } \\
\cline { 3 - 5 } & & 2 & 4 & Staff \\
\hline HDFC Bank & 4 & 3 & 6 & 8 \\
\hline ICICI Bank & 5 & 3 & 6 & 12 \\
\hline Axis Bank & 5 & 1 & 2 & 4 \\
\hline Yes Bank & 1 & 1 & 2 & 4 \\
\hline Kotak Mahindra Bank & 2 & 11 & 22 & 4 \\
\hline IndusInd Bank & 1 & 18 & & \\
\hline Total & 18 & & \\
\hline
\end{tabular}

\section{Data Collection Method}

As an essential part of the study, the primary data were collected by the researcher for a period of 6 months from July 2017 to December 2017. The primary data were collected from 66 employees with the help of schedule. The secondary data were collected from journals, magazines, government reports, books and unpublished dissertations. The data collected for the study were edited, quantified, categorized and tabulated, and analyzed to arrive at useful conclusions.

\section{Analysis and Discussions}

A typical discriminant function will be of the following form:

Where,

$$
Z=a_{0}+a_{1} X_{1}+a_{2} X_{2}+\ldots \ldots \ldots+a_{n} X_{n}
$$

$\mathrm{a}_{0}$ - Constant

$a_{1}, a_{2}, \ldots . . a_{n}-$ Discriminant function coefficients of the independent variables $X_{1}, X_{2}, \ldots . . X_{n}$, respectively.

The following items relating to practical utility of CRM practices were included this model to identify the variables which discriminate between managers and staff.

1. Increases customer base

2. Retention of existing customers

3. Increases bank image

4. Higher order of customer satisfaction

5. Solves customers' problems

6. Growth in banking service

7. Customer inclusion in policy making

8. Attracts new customer

9. Enhances customers loyalty

10. Increases bank performance and productivity

11. Promotes customer awareness

12. Boosts customers' confidence

13. Creates friendly environment

The result of the discriminat function analysis is given in Table 2 with the values of discriminant function coefficients for each of the discriminating variable. 
Table 2: Canonical discriminant function coefficients

\begin{tabular}{|l|c|}
\hline \multicolumn{1}{|c|}{ Variables } & Function \\
\hline Increases customer base & 0.413 \\
\hline Retention of existing customers & 0.248 \\
\hline Increases bank image & 0.241 \\
\hline Higher order of customer satisfaction & 0.044 \\
\hline Solves customers' problems & -0.028 \\
\hline Growth in banking service & 0.318 \\
\hline Customer inclusion in policy making & 0.399 \\
\hline Attracts new customer & 0.640 \\
\hline Enhances customers loyalty & 0.272 \\
\hline Increases bank performance and productivity & 0.266 \\
\hline Promotes customer awareness & 0.226 \\
\hline Boosts customers' confidence & 0.238 \\
\hline Creates friendly environment & 0.494 \\
\hline (Constant) & -12.291 \\
\hline
\end{tabular}

Using the values given in Table 2, the discriminant function $(\mathrm{Z})$ for the problem under study can be written as:

$\mathrm{Z}=-12.291+0.413 \mathrm{X} 1+0.248 \mathrm{X} 2+0.241 \mathrm{X} 3+0.044 \mathrm{X} 4-$ $0.028 \times 5+0.318 \times 6$

$+0.399 \times 7+0.640 \times 8+0.272 \times 9+0.266 \times 10+0.226 \times 11+0$. $238 \mathrm{X} 12+0.494 \mathrm{X} 13$-- (A)

Where,

$\mathrm{X} 1=$ Increases customer base

$\mathrm{X} 2=$ Retention of existing customers

$\mathrm{X} 3=$ Increases bank image

$\mathrm{X} 4=$ Higher order of customer satisfaction

$\mathrm{X} 5=$ Solves customers' problems

$\mathrm{X} 6=$ Growth in banking service

$\mathrm{X} 7=$ Customer inclusion in policy making
$\mathrm{X} 8=$ Attracts new customer

$\mathrm{X} 9=$ Enhances customers loyalty

$\mathrm{X} 10=$ Increases bank performance and productivity

$\mathrm{X} 11=$ Promotes customer awareness

$\mathrm{X} 12=$ Boosts customers' confidence

$\mathrm{X} 13=$ Creates friendly environment

Table 3 provides the multivariate aspect of the model given under the heading 'Cannonical Discriminant Function'. Note that discriminant function is significant (Wilk's lambda and chi-square test values indicate that the model is significant at $1 \%$ level) and displays a correlation of 0.570 which explains that there is a good correlation between the grouping variable and the independent variables.

Table 3: Cannonical discriminant function

\begin{tabular}{|c|c|c|c|c|}
\hline Canonical Correlation & Wilk's' Lambda & Chi-square & DF & Result. \\
\hline 0.570 & 0.675 & 22.614 & 13 & Significant \\
\hline
\end{tabular}

Classification: Once the discriminant function is arrived at, then the efficiency of the function as to, how accurately it predicts the employees into the respective groups must be assessed. For this, a classification matrix is to be developed using actual and predicted group membership of the employees. Before a classification matrix can be measured, the group centroids (means), cutting score and prior probabilities of each group are to be considered.

Group Centroids: Using the discriminant function given in (A), the discriminant score for each employee is calculated by substituting the values for discriminating variables from the analysis data. Then means scores for managers group $\left(Z_{o}\right)$ and staff group $\left(Z_{1}\right)$ are calculated, which are called group centroids are given Table 4.
Table 4: Canonical discriminant functions evaluated at group means

\begin{tabular}{|l|c|}
\hline \multicolumn{1}{|c|}{ Designation } & Function \\
\hline Manager & 0.967 \\
\hline Staff & -0.483 \\
\hline
\end{tabular}

Table 5: Prior probabilities for groups

\begin{tabular}{|l|c|c|}
\hline Designation & $\begin{array}{c}\text { Prior } \\
\text { Probabilities }\end{array}$ & $\begin{array}{c}\text { No. of } \\
\text { Respondents }\end{array}$ \\
\hline Manager & 0.333 & 22 \\
\hline Staff & 0.667 & 44 \\
\hline Total & 1.000 & 66 \\
\hline
\end{tabular}

\section{Cutting Score}

Using the sample sizes and centroids for these two groups, cutting score is calculated as follows:

$$
\mathrm{Z}_{\mathrm{c}}=\frac{\mathrm{N}_{0} \mathrm{Z}_{0}+\mathrm{N}_{1} \mathrm{Z}_{1}}{\mathrm{~N}_{0}+\mathrm{N}_{1}}
$$


Where,

$\mathrm{Z}_{\mathrm{c}}=$ Cutting score

$Z_{0}=$ Centroid for managers

$\mathrm{Z}_{1}=$ Centroid for staff

$\mathrm{N}_{0}=$ Sample size of managers group

$\mathrm{N}_{1}=$ Sample size of staff group

Hence, substituting the respective values the cutting score is:

$Z_{c}=[22 *(0.967)+44 *(-483] /(22+44)=0.00$

Against this cutting score, each employee's discriminant score is examined. If his score is greater than $Z_{c}$ value, then he is classified in managers group, otherwise in staff group.

\section{Prior Probabilities}

A prior probabilities are calculated for each group based on the proportionate size of the sample in the respective groups. Using these prior probabilities, centroids and cutting score, the classification matrix is formed. Table 6 is the classification matrix giving how many of the employees were correctly classified into the respective groups and the overall correct classification percentage. Thus, it is seen that the discriminant function has predicted 97.30 per cent of the employees correctly in the managers group and 32.70 per cent of the employees in the staff group, and on the whole classified 84.40 per cent of the employees correctly.

Table 6: Classification result

\begin{tabular}{|c|c|c|c|c|c|}
\hline \multicolumn{2}{|c|}{} & \multicolumn{2}{c|}{ Predicted Group Membership } & \multirow{2}{*}{ Total } \\
\hline \multirow{3}{*}{ Original } & No. & Designation & Manager & Staff & \\
\cline { 3 - 6 } & & Staff & 13 & 9 & 22 \\
\cline { 2 - 5 } & $\%$ & Manager & 59.1 & 38 & 44 \\
\cline { 3 - 6 } & & Staff & 13.6 & 40.9 & 100.0 \\
\hline
\end{tabular}

$77.30 \%$ of original grouped cases correctly classified

Pooled within-groups correlations between discriminating variables and standardized canonical discriminant functions, the variables are ordered by absolute size of correlation within function.

Table 7: Structure matrix

\begin{tabular}{|l|c|c|}
\hline \multicolumn{1}{|c|}{ Variables } & Function (R) & $\mathbf{R}^{\mathbf{2}}$ \% \\
\hline Attracts new customer & 0.491 & 24.11 \\
\hline Creates friendly environment & 0.354 & 12.53 \\
\hline Growth in banking service & 0.306 & 9.36 \\
\hline Boosts customers' confidence & 0.249 & 6.20 \\
\hline Increases bank image & 0.223 & 4.97 \\
\hline Enhances customers loyalty & 0.182 & 3.31 \\
\hline Promotes customer awareness & 0.163 & 2.66 \\
\hline Increases bank performance and productivity & 0.141 & 1.99 \\
\hline Retention of existing customers & 0.118 & 1.39 \\
\hline Customer inclusion in policy making & 0.103 & 1.06 \\
\hline Increases customer base & 0.090 & 0.81 \\
\hline Higher order of customer satisfaction & 0.029 & 0.08 \\
\hline Solves customers' problems & -0.028 & 0.08 \\
\hline
\end{tabular}

\section{Results}

The results showed that 'attracts new customer' is the maximum discriminating variable $\left(\mathrm{R}^{2 \%} \%=24.11 \%\right)$ between managers and staff, followed by 'creates friendly environment' (12.53\%), 'growth in banking service' $(9.36 \%)$ and 'boosts customer confidence' $(6.20 \%)$. The contribution of all other items discriminating between managers and staff are less than $5 \%$.

\section{Suggestions}

1. Customers of the new generation private banks would get the feeling of security while transacting with the banks. The banks ought to practice transparency and accuracy in their transactions and make certain that customers benefit and get complete satisfaction. Further, the new generation private banks must consider positioning themselves on the minds of customers that they are customer oriented and all the time explore ways to make banking easier for them.

2. A top-down customer relationship management centered approach that starts with the top management, percolating and permeating to all levels of the customer relationship management is necessary for new generation private banks. 
Customer relationship management audit by independent teams should be done so as to make out the existing lacunae, and to tackle the loopholes in the customer relationship management strategy as per the recommendations of the audit report.

3. The employees who interface the customers directly are ought to be empathetic and should be able to understand the customer requirements. Training the human resource would help the new generation private banks to retain their customers and attract more. The employees of the new generation private banks should be trained on technical and behavioural aspects, so that banks can deliver fast and prompt services.

4. The new generation private banks shall get on customer contact programmes so as to understand the problems and expectations of the customers. For this purpose, customers meet, special events, direct mails, greeting cards, etc. can be used to get in touch with customers.

5. The new generation private banks shall constitute a "Customer Relationship Committee" in every branch consisting of staff and customers of various segments. The customers can lodge their complaints and offer suggestions on different matters pertaining to banking services. These complaints shall be discussed at the Customer Relationship Committee meeting every month.

\section{Conclusion}

The successful mantra for business is to focus on customer needs, wants and demands. In order to survive in the vibrant business environment, the value of relationship differentiates from one organization to another. Customer relationship management becomes a critical means of developing and maintaining customer loyalty. It facilitates enhanced performance of the business at every stage of the customer relationship. It is necessary for new generation private banks to create a special bondage with the customers to face challenges arising out of stiff competition. Hence, it is an imperative for service providers to meet the target customers' satisfaction with quality of services expected by them. The new generation private banks need to distinguish themselves by offering value-added service and building long-term relationships with their customers. The study will provoke the authority concerned to take some positive measures for improving the customer relationship management of the new generation private banks.

\section{References}

1. Bolanle Odunlami. Impact of Customer Satisfaction on Customer Retention: A Case Study of a Reputable Bank in Oyo, Nigeria. International Journal of Managerial Studies and Research. 2015;3(2):42-53.

2. Emmah Kemunto Mecha, Ogutu Martin and Sixtus Momanyi Ondieki. Effectiveness of Customer Retention Strategies: A Case of Commercial Banks, Kenya.
International Journal of Business and Management. 2015;10(10):270-275.

3. Gaurang Trivedi and Richard Remedios. Internet Banking \& Customer Retention: A Study on the Impact of Internet Banking on Customer Retention of HDFC Bank. GALAXY International Interdisciplinary Research Journal. 2014;2(2):218-234.

4. Janet C. Siele. Financial Factors Affecting Customer Retention in Commercial Banks in Kenya: A Case of Commercial Banks in Thika Town, Kenya. International Journal of Social Sciences and Information Technology. 2016;2(4)459-474.

5. Manickavasakam, T.K and Velavan, A. (2012). A Study of Banking Customer Retention through Customer Satisfaction in Dharmapuri. Namex International Journal of Management Research. 2012;2(2):9-15.

6. Msoka Caroline, M and Msoka Elizabeth. Determinants of Customer Retention in Commercial Banks in Tanzania. Journal of Finance and Bank Management. 2014;2(1)930.

7. Mutegi Nicholas Mugambi and Assumptah W. Kagiri. Effects of Customer Retention Strategy on Performance of Commercial Banks in Kenya. International Journal of Science and Research. 2013;4(6)44-49.

8. Sundaresalingam, P and Haranya, M. A Study on Customer Retention at Canara Bank, Palani. International Journal of Engineering and Management Research. 2012;2(1):1-7.

9. Winfred Nganda Mbithi. Challenges of Customer Retention in the Kenyan Banking Sector: A Case Study of KCB Treasury Square Branch, Mombasa. International Journal of Sciences: Basic and Applied Research. 2013;(12)1:24-132. 